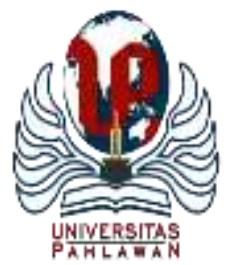

Edukatif : Jurnal Ilmu Pendidikan Volume 3 Nomor 6 Tahun 2021 Halm 4794 - 4801

EDUKATIF: JURNAL ILMU PENDIDIKAN

Research \& Learning in Education

https://edukatif.org/index.php/edukatif/index

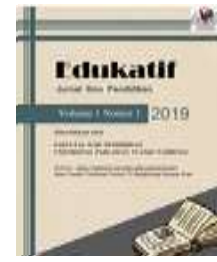

\title{
Analisis Media Pembelajaran Quizizz dalam Pembelajaran Daring pada Siswa Tingkat Sekolah Dasar
}

\author{
Gamar Al Haddar $^{1 凶}$, Maulana Adam Juliano ${ }^{2}$ \\ Universitas Widya Gama Mahakam Samarinda, Indonesia ${ }^{1,2}$ \\ E-mail : gamarhaddar19@gmail.com ${ }^{1}, \underline{\text { maulanajuliano47@ gmail.com }}^{2}$
}

\begin{abstract}
Abstrak
Penelitian ini dilatar belakangi pada penggunaan media pembelajaran Quizizz dalam pembelajaran daring. Penelitian ini bertujuan untuk mengetahui menganalisis media pembelajaran Quizizz dalam pembelajaran daring pada siswa kelas IV di SD Muhammadiyah 6 Samarinda Utara tahun pembelajaran 2020/2021. Teknik pengumpulan data menggunakan teknik wawancara dan dokumentasi. Teknik analisis data yang digunakan peneliti yaitu reduksi data, penyajian data dan penarikan kesimpulan. Teknik keabsahan data yang digunakan peniliti adalah triangulasi sumber. Hasil penelitian mengenai menganalisis media pembelajaran Quizizz dalam pembelajaran daring di SD Muhammadiyah 6 Samarinda Utara bahwa menggunakan aplikasi Quizizz dapat menumbuhkan motivasi dan minat belajar siswa. Menggunakan aplikasi Quizizz juga menjadikan proses pembelajaran daring lebih menyenangkan. Adapun kendala dalam penggunaan aplikasi Quizizz adalah jaringan internet. Kemudian penggunaan kouta internet untuk mengakses aplikasi Quizizz juga menjadi kendala karena susah menghubungkan ke-jaringan internet. Adapun manfaat ketika menggunakan aplikasi Quizizz membuat proses pembelajaran daring lebih variatif dan efisien. Kelebihan menggunakan aplikasi Quizizz hasil belajar dapat dilihat secara langsung. Penggunaan aplikasi Quizizz juga dapat mengevaluasi siswa secara mandiri. Aplikasi Quizizz hanya untuk mengetahui kemampuan siswa dalam ranah kognitif. Penggunaan media pembelajaran berbasis online seperti aplikasi Quizizz pada siswa kelas IV SD Muhammadiyah 6 Samarinda utara dapat dikatakan efektif.
\end{abstract}

Kata Kunci: Media Pembelajaran Quizizz, Pembelajaran Daring

\begin{abstract}
The background of this study is the use of learning media Quizizz in online learning. This study aimed to find out how to analyze learning media Quizizz in online learning for fourth-grade students at SD Muhammadiyah 6 North Samarinda in the 2020/2021 academic year. Data collection techniques used by the researcher are interview and documentation techniques. The data analysis technique used by the researcher is data reduction, data presentation, and drawing conclusion. The data validity technique used by the researcher is source triangulation. The results of the study on analyzing the learning media Quizizz in online learning at SD Muhammadiyah 6 North Samarinda showed that using the application Quizizz can foster student motivation and interest in learning. Using the application Quizizz also makes online learning more enjoyable. The obstacle in using the application Quizizz is the internet network. Then the use of internet quota to access the application is Quizizz also an obstacle because it is difficult to connect to the internet network. The benefits of using the application Quizizz make the online learning process more varied and efficient. The advantages of using the application Quizizz can be seen directly. The use of the application Quizizz can also evaluate students independently. Application Quizizz only to find out students' abilities in the cognitive realm. The use of learning media online-based such as the application Quizizz for fourthgrade students of SD Muhammadiyah 6 North Samarinda can be said to be effective.
\end{abstract}

Keywords: Learning Media Quizizz, Online Learning

Copyright (c) 2021 Gamar Al Haddar, Maulana Adam Juliano

$\triangle$ Corresponding author:

Email : gamarhaddar19@gmail.com

DOI : https://doi.org/10.31004/edukatif.v3i6.1512

ISSN 2656-8063 (Media Cetak)

ISSN 2656-8071 (Media Online)

Edukatif : Jurnal Ilmu Pendidikan Vol 3 No 6 Tahun 2021 p-ISSN 2656-8063 e-ISSN 2656-8071 


\section{PENDAHULUAN}

Pendidikan merupakan kebutuhan bagi setiap siswa. Menurut Undang- undang No. 20 Tahun 2003 tentang sistem pendidikan nasional (Sanjaya, 2016) Pendidikan adalah usaha sadar dan terencana yang dilakukan oleh guru agar siswa secara aktif mengembangkan potensi berupa pengetahuan, sikap, minat dan bakat sehingga memiliki kekuatan spiritual keagamaan, pengendalian diri, kepribadian, kecerdasan, akhlak mulia, serta keterampilan yang diperlukan dirinya, masyarakat, bangsa dan negara. Pendidikan adalah usaha sadar dan terencana yang menjadikan siswa menjadi lebih produktif. Selain itu pendidikan juga bertujuan untuk mengembangkan potensi pada siswa dari segi kognitif (pengetahuan), psikomotorik (keterampilan) dan afektif (sikap).

Pendidikan juga tidak dapat dilakukan dengan asal- asalan, pendidikan sendiri mempunyai sistem terencana yang didalamnya terdapat standar proses pendidikan (Sanjaya, 2016). Pendidikan tidak dapat dilaksanakan secara outodidak karena memiliki sistem yang terencana. Menurut Peraturan Pemerintah No.19 Tahun 2015 Bab 1 Pasal 1 Ayat 6 (Sanjaya, 2016) standar proses pendidikan adalah standar nasional pendidikan yang berkaitan dengan pelaksanaan pembelajaran dan standar kompetensi lulusan. Standar proses pendidikan terdiri dari pelaksanaan pembelajaran yang berkaitan dengan kegiatan belajar dan pembelajaran, sedangkan standar kompetensi kelulusan merupakan indikator untuk menentukan pelakasanaan pembelajaran (Sanjaya, 2016). Standar proses pendidikan merupakan suatu sistem yang di dalamnya mengatur proses belajar dan pembelajaran untuk mencapai kompetensi kelulusan.

Pelaksanaan pembelajaran yang efektif dan efisien akan mewujudkan kompetensi kelulusan sesuai dengan tujuan pendidikan. Pendidikan dapat dikatakan berhasil apabila mampu menciptakan sumber daya manusia yang produktif dan berakhlak baik. Pendidikan dapat berubah sesuai dengan berjalannya waktu. Seperti halnya tahun ini dimana terjadi pandemi Covid- 19 yang semua negara terkena dampaknya, khususnya dalam sistem pendidikan. Pandemi Covid- 19 berasal dari Wuhan, China yang diakibatkan virus severe acute respiratory syndromecoronavirus 2 (SARS- CoV-2) sering disebut virus corona. Pandemi Covid- 19 masuk ke Negara Kesatuan Republik Indonesia pada tahun lalu yang mengakibatkan perubahan pada sistem pendidikan. Perubahan sistem pendidikan juga terjadi pada standar proses pendidikan. Perubahan standar proses pendidikan juga akan terjadi pada pelaksanaan pembelajaran. Selain itu perubahan pelaksanaan pembelajaran juga terjadi pada kegiatan proses belajar dan pembelajaran.

Belajar menjadi bagian terpenting dalam sistem pendidikan. Proses belajar adalah kemampuan siswa untuk mendapatkan informasi dan pengalaman baru dalam bentuk lisan, tulis, karya, dan tingkah laku (Susanto, 2016). Proses belajar dilaksanakan untuk meningkatkan kemampuan siswa dari segi pengetahuan, sikap dan keterampilan. Melalui proses belajar peserta didik dapat berfikir positif dan berakhlak baik. Perubahan akibat pandemi Covid- 19 juga terjadi pada kegiatan proses belajar. Proses belajar yang biasannya di laksanakan di dalam kelas menjadi belajar dirumah. Proses belajar daring adalah kegiatan belajar jarak jauh yang menggunakan alat bantu dan memanfaatkan internet sebagai sarana belajar (Pohan, 2020). Proses belajar memanfaatkan media internet sebagai sarana interaksi siswa dan guru yang menggunakan alat bantu smartphone, gadget, laptop dan komputer. Perubahan kegiatan proses belajar akan terjadi pada kegiatan proses pembelajaran.

Proses pembelajaran adalah kegiatan yang dilakukan guru memberi intruksi atau petunjuk kepada siswa berupa pengetahuan dan pengalaman dalam bentuk lisan, tulis, karya dan sikap (Dimyanti, 2015). Pelaksanaan pembelajaran tidak dapat dilakukan dengan asal- asalan. Sebelum melaksanakan kegiatan mengajar guru harus menyiapkan materi ajar, media dan metode yang akan digunakan dalam proses pembelajaran (Sanjaya, 2016). Menyiapkan materi ajar, media dan metode pembelajaran akan membantu proses belajar peserta didik.

Saat ini proses pembelajaran berbeda dengan tahun lalu. Saat ini proses pembelajaran dilakukan secara daring. Proses pembelajaran secara daring diakibatkan karena adanya Covid- 19. Pandemi Covid-19 menjadi 
hambatan dalam proses pembelajaran. Proses pembalajaran yang biasanya di dalam kelas dan bertatap muka dengan siswa harus di tempat masing- masing. Guru juga kesulitan memilih metode dan media pembelajaran yang akan digunakan untuk menyampaikan materi pelajaran maupun melihat kemampuan siswa setelah melakukan proses pembelajaran. Guru juga kebingungan untuk menciptakan suasana belajar yang interaktif dalam kegiatan pembelajaran daring. Sehingga kegiatan belajar dan pembelajaran yang biasanya menyenangkan menjadi membosankan.

Kemajuan teknologi di era revolusi industri 4.0 membuat dunia pendidikan menjadi lebih mudah. Pembelajaran E-learning yaitu memanfaatkan teknologi informasi dan komunikasi sebagai alat bantu dalam proses belajar dan pembelajaran (Elyas, 2018). Proses belajar dan pembelajaran menggunakan internet sebagai sarana interaksi antara guru dan siswa seperti media pembelajaran Quizizz. Quizizz adalah sebuah wab tol berbentuk game yang digunakan untuk kegiatan pembelajaran daring (Suhartatik, 2020). Media pembelajaran Quizizz sangat tepat digunakan untuk proses belajar dan pembelajaran daring selama pandemi Covid- 19. Sehingga selama pandemi Covid- 19 proses belajar dan pembelajaran tetap berlangsung dan menyenangkan.

Media pembelajaran Quizizz sangat penting digunakan dalam proses pembelajaran daring. Fitur- fitur yang ada di dalam Quizizz mampu memberikan pengalaman belajar bagi siswa. Tidak hanya itu saja media pembelajaran Quizizz juga mampu membatu guru membuat materi maupun pertanyaan yang akan diberikan pada siswa dalam pembelajaran daring. Media pembelajaran Quizizz juga memberikan kemudahan guru memberikan soal pelajaran sehingga siswa dapat mengerjakan soal hanya pada hari yang sudah ditentukan sehingga tidak terjadi penumpukkan tugas dalam proses belajar daring.

Berdasarkan hasil observasi awal yang dilakukan peneliti dampak dari pademi Covid- 19 juga mengubah proses belajar dan pembelajaran di SD Muhammadiyah 6 Samarinda Utara. Perubahan juga terjadi pada sistem proses belajar dan pembelajaran di SD Muhammadiyah 6 diantaranya adalah kegiatan belajar dan pembelajaran yang seharusnya dilakukan di dalam kelas menjadi ditempat masing- masing. Kemudian proses belajar dan pembelajaran menggunakan media internet sebagai sarana untuk menyampaikan materi maupun untuk mengetahui kemampuan siswa. Media yang digunakan guru dalam proses belajar dan pembelajaran di SD Muhammadiyah 6 Samarinda Utara adalah media internet seperti whataap dan youtube. Pengguanaan media internet seperti whataap dan youtube tidak membuat siswa menjadi interaktif sehingga siswa cepat bosan. Akan tetapi ada beberapa guru yang kreatif dan inovatif menggunakan media pembelajaran berbasis internet yang dapat membuat siswa menjadi interaktif salah satunya adalah Quizizz.

Perkembangan teknologi di era revolusi industri 4.0 yang begitu cepat membawa angin segar dalam dunia pendidikan. Perkembangan teknologi komunikasi dan informasi berbasis internet membuat proses pembelajaran begitu mudah tanpa harus melakukan tatap muka salah satunya adalah Quizizz. Berdasarkan ahsil observasi di SD Muhammadiyah 6 Samarinda Utara ada beberapa guru yang memanfaatkan media berbasis internet yaitu Quizizz. Maka dari itu peneliti tertarik untuk meneliti tentang Analisis Media Pembelajaran Quizizz Dalam Pembelajaran Daring Kelas IV di SD Muhammadiyah 6 Samarinda Utara Tahun Pembelajaran 2020/2021.

\section{METODE PENELITIAN}

Jenis penelitian ini adalah kualitatif. Adapun Metode penelitian yang digunakan yakni deskriptif. Menurut Restu Kartiko Widi (Dewi \& Asrori, 2019) metode deskriptif adalah metode yang menggambarkan semua data dan keadaan obyek/subyek, setelah itu dianalisis dan dibandingkan dengan kenyataan yang ada dan kemudian peneliti mencoba untuk menyelesaikan masalah Hasil penelitian adalah data yang diperoleh dari hasil pengumpulan data sesuai dengan keadaan dan situasi sebenarnya.

Hasil penelitian ini adalah hasil dari pengumpulan data yang dillakukan peneliti melalui kegiatan wawancara maupun dokumentasi sesuai dengan keadaan yang ada. Pemaparan penelitian ini berdasarkan fokus pada penggunaan media pembelajaran Quizizz dalam pembelajaran daring. 
Penelitian ini dilakukan di kelas IV SD Muhammadiyah 6 Samarinda Utara. Penelitian yang dilakukan peneliti menggunakan teknik pengumpulan data purposive sampling yang menjadikan 11 orang menjadi sampel penelitan. Pengambilan sampel ini dilakukan melalui pertimbangan tertentu dan hanya mengambil orang yang bersangkutan langsung dan ikut serta terlibat dalam kegiatan pembelajaran daring menggunakan media pembelajaran Quizizz,. 11 orang akan menjadi narasumber yang akan dimintai keterangan peneliti dalam kegiatan wawancara.

Hasil wawancara ini akan direduksi data dimana peneliti akan memilah data yang sudah terkumpul kemudian dipilih pada hal- hal pokok, selanjutnya dipaparkan dalam bentuk teks naratif dan disimpulkan. Teknik keabhsahan data dilakukan dengan triangulasi sumber yaitu dilihat dari hasil wawancara guru, siswa dan orang tua/wali murid.

\section{HASIL DAN PEMBAHASAN PENELITIAN}

Media pembelajaran merupakan suatu alat yang digunakan guru untuk mempermudah menyampaikan informasi maupun memberi intrukasi kepada siswa dalam proses pembelajaran. Media pembelajaran dapat disesuaikan dengan apa yang dibutuhkan siswa selama kegiatan proses belajar dan pembelajaran untuk mencapai tujuan pembelajaran. Selama pandemi covid- 19 membuat proses pembelajaran menjadi daring. Pembelajaran daring merupakan kegiatan yang dilakukan guru dalam menyampaikan informasi atau intruksi kepada siswa tanpa harus bertatap muka. Sehingga guru harus menyiapkan media pembelajaran yang berbeda salah satunya adalah Quizizz. Menggunakan aplikasi Quizizz mampu memberikan pengalaman belajar kepada siswa walaupun proses pembelajaran dilakukan secara daring. Salah satu pengalaman belajar adalah dapat memotivasi belajar siswa. Hal ini dikarenakan guru memberikan soal melalui aplikasi Quizizz yang mempunyai banyak fitur menarik. Fitur- fitur yang menarik pada aplikasi Quizizz mampu memotivasi siswa dalam proses pembelajaran daring. Menurut orang tua selama penggunaan aplikasi Quizizz dalam proses pembelajaran daring anak termotivasi lebih giat belajar. Hal ini dapat diperkuat sebagimana data dokumen yang ditemukan yaitu hasil belajar yang dapat dilihat pada portal guru diaplikasi Quizizz, kemudian beberapa siswa mendapatkan nilai diatas KKM (kriteria ketuntasan minimum) dan antusias siswa menjawab semua pertanyaan yang diberikan guru sangat tinggi. Hal ini juga sesuai dengan teori yang dikemukakan oleh Arsyad (2017) bahwa menggunakan media pembelajaran dapat menarik perhatian siswa sehingga dapat memotivasi siswa. Hal ini juga didukung oleh teori Gagne (Dimyanti, 2015) motivasi adalah usaha yang menggerakkan dan mengarahkan siswa dalam proses belajar.

Penggunaan aplikasi Quizizz dalam pembelajaran daring juga dapat menumbuhkan minat belajar siswa. Guru memberikan soal di aplikasi Quizizz dengan durasi waktu yang berbeda berdasarkan tingkat kesulitan soal, sehingga siswa merasa tertantang dan ingin menjawab semua pertanyaan. Siswa merasa tertantang dan menjawab semua pertanyaan. Menurut orang tua/wali murid selama menggunakan aplikasi Quizizz dalam pembelajaran daring anak menjawab semua pertanyaan yang diberikan guru. Hal ini dapat diperkuat dari hasil telaah dokumen yang ditemukan yaitu hasil belajar siswa setelah menjawab pertayaan diaplikasi Quizizz. Dokumen rekapan nilai guru yang mana siswa menjawab semua pertanyaan yang diberikan guru melalui aplikasi Quizizz,. Hal ini juga sesuai dengan teori yang dikemukakan oleh Arsyad (2017) bahwa dengan menggunakan media pembelajaran mampu menumbuhkan minat belajar siswa. Hal ini juga didukung oleh teori Kurt Lewin (Dimyanti, 2015) bahwa dalam kegiatan belajar siswa akan dihadapkan pada satu masalah yang harus diselesaikan seperti halnya mempelajari bahan belajar, maka akan timbul minat belajar untuk mempelajari bahan belajar tersebut

Penggunaan aplikasi Quizizz juga dapat menjadikan proses belajar dan pembelajaran daring menjadi menyenangkan. Guru yang memberikan soal dan memanfaatkan fitur- fitur yang ada dalam aplikasi Quizizz mampu menarik perhatian siswa sehingga siswa senang dalam mengikuti proses pembelajaran daring. Siswa tertarik dan senang karena diaplikasi Quizizz terdapat tampilan fitur yang menarik. Menurut orang tua/wali 
murid selama penggunaan aplikasi Quizizz siswa sangat senang mengikuti proses pembelajaran daring dikarenakan tampilan fitur- fitur aplikasi yang menarik. Hal ini juga diperkuat dari telaah dokumen yakni tampilan fitur aplikasi Quizizz yang menarik yang hanya dapat dilihat pada portal siswa. Hal ini sesuai dengan teori yang dikemukakan Arsyad (2017) bahwa menggunakan media pembelajaran dapat membuat proses pembelajaran lebih menyenangkan. Sebagaimana dalam teori Amanah (2021) pengunaan aplikasi Quizizz dapat membuat proses pembelajaran lebih menyenangkan karena terdapat berbagai fitur aplikasi yang membuat siswa senang.

Kendala dalam pembelajaran daring menggunakan aplikasi Quizizz salah satunya adalah jaringan internet kurang baik. Ketika guru memberikan soal pada aplikasi Quizizz terkadang siswa tidak bisa login karena terkendala jaringan internet. Menurut siswa dan orang tua/wali murid apabila jaringan buruk akan mempengaruhi proses pembelajaran daring menggunakan aplikasi Quizizz yaitu tidak bisa login dan bisa keluar dari aplikasi Quizizz. Hal ini sesuai dengan hasil penelitian yang dilakukan oleh Salsabila (2020) bahwa jaringan internet yang kadang- kadang berubah sehingga dapat menghambat jalannya proses pembelajaran menggunakan aplikasi Quizizz.

Selanjutnya kendala dalam pembelajaran daring adalah kouta internet. Kouta internet yang tidak dapat menghubungkan ke jaringan internet menyebabkan siswa tidak dapat mengakses aplikasi Quizizz. Menurut orang tua/wali murid menggunakan kouta internet menjadi kendala dalam penggunaan aplikasi Quizizz karena jaringan internet tidak setabil dan berubah- ubah, sehingga mencari cara lain untuk mengakses internet yaitu menggunakan Wifi karena jaringan internet lebih stabil. Berdasarkan hasil penelitian yang dilakukan oleh Salsabila (2020) bahwa jaringan internet yang kadang- kadang berubah dapat menghambat jalannya proses pembelajaran menggunakan aplikasi Quizizz.

Manfaat menggunakan aplikasi Quizizz adalah ketepatan waktu mengerjakan tugas. Guru dapat mengatur kapan batas waktu mengerjakan tugas sehingga siswa selalu mengerjakan tugas sesuai dengan batas waktu yang diberikan guru. Siswa mengerjakan tugas sesuai dengan batas waktu yang ditentukan. Menurut orang tua/wali murid anak selalu mengerjakan tugas tepat waktu. Sesuai dengan telaah data dokumen yang ditemukan yaitu guru dapat mengatur batas waktu mengerjakan tugas maupun persoal, sehingga siswa hanya dapat mengerjakan tugas sesuai dengan batas waktu yang telah ditentukan, namun hanya dapat dilakukan melalui portal guru diaplikasi Quizizz. Berdasarkan hasil penelitian yang dilakukan oleh Salsabila (2020) bahwa menggunakan aplikasi Quizizz guru dapat memanagament waktu sesuai dengan kebutuhan proses pembelajaran.

Pembelajaran daring juga lebih variatif dan efisien menggunakan aplikasi Quizizz. Guru memanfaatkan fitur aplikasi Quizizz supaya pembelajaran daring lebih variatif sehingga siswa tidak bosan. Guru mengatur durasi waktu persoal sehingga tidak membutuhkan waktu lama dalam proses pembelajaran daring. Siswa tidak merasa bosan dan tidak membutuhkan waktu lama dalam pembelajaran daring menggunakan aplikasi Quizizz. Menurut orang tua anak tidak bosan dan tidak membutuhkan waktu lama dalam pembelajaran daring menggunakan aplikasi Quizizz. Berdasarkan dokumen yang telah ditemukan yaitu guru dapat mengatur batas waktu mengerjakan tugas maupun persoal melalui portal guru diaplikasi Quizizz dan kemudian juga dapat dilihat dari tampilan aplikasi Quizizz yang menarik membuat siswa tidak bosan, yang hanya dapat dilihat pada portal siswa. Sebagaimana teori yang dikemukakan oleh Sudjana dan Rivai (Arsyad, 2017) bahwa menggunakan media pembelajaran akan lebih variaif, sehingga siswa tidak bosan dalam mengikuti proses pembelajaran. Hal Ini juga didukung oleh teori Arsyad (2017) bahwa menggunakan media pembelajaran sebagai pemecah masalah waktu, indra dan tempat.

Kelebihan menggunakan aplikasi Quizizz adalah hasil belajar dapat terlihat secara langsung ketika siswa sudah mengerjakan soal. Guru dapat melihat hasil belajar siswa dan mempunyai rekap nilai sendiri. Siswa dapat melihat hasil belajar secara langsung berupa skor dan dapat melihat peringkatnya. Menurut orang tua/wali murid siswa dapat melihat hasil belajar dan melihat rangkingnya. Berdasarkan kajian dokumen yang 
ditemukan yaitu hasil belajar siswa yang dapat dilihat melalui portal aplikasi siswa. Kemudian guru juga dapat melihat hasil belajar siswa melalui rekap nilai pada portal guru diaplikasi Quizizz. Sebagaimana teori yang dikemukakan oleh Salsabila (2020) bahwa menggunakan aplikasi Quizizz hasil belajar dapat didownload dan dapat dilihat secara langsung.

Adapun kelebihan penggunaan media pembelajaran Quizizz mampu mengevaluasi siswa secara mandiri dan siswa dapat remedial secara langsung. Guru memberikan soal melalui aplikasi Quizizz dan memberikan jawaban benar ketika siswa menjawab pertanyaan salah. Siswa dapat mengetahui jawaban yang benar ketika menjawab pertanyaan salah dan guru memberikan kesempatan untuk mengulang kembali. Menurut orang tua/wali murid ketika menggunakan aplikasi Quizizz anak dapat melihat jawaban yang benar apabila anak menjawab pertanyaan salah dan anak diberikan kesempatan untuk mengulang apabila mendapat nilai rendah. Sebagaimana kajian dokumen yang ditemukan yaitu gambar pada portal siswa diaplikasi Quizizz, yang mana siswa dapat melihat jawaban benar berwarna hijau dan salah bewarna merah. Dapat dilihat juga gambar hasil belajar yang hanya bisa dilihat melalui portal guru diaplikasi Quizizz, kemudian dapat dilihat juga seberapa banyak upaya siswa mengerjakan soal. Hal ini juga didukung oleh hasil penelitian yang dilakukan oleh Salsabila (2020) bahwa penggunaan aplikasi Quizizz dapat melihat jawaban benar apabila menjawab soal salah sehingga siswa dapat mengevaluasi secara mandiri.

Pembelajaran daring menggunakan aplikasi Quizizz hanya mampu untuk mengetahui kemampuan siswa dalam ranah kognitif guru hanya memberikan soal kepada siswa melalui aplikasi Quizizz untuk mengetahui kemampuan siswa dalam ranah kognitif. Siswa bisa menjawab pertanyaan yang diberikan guru melalui aplikasi Quizizz dan siswa juga bisa membantu orang tua. Menurut orang tua/wali murid anak dapat mengerjakan soal yang diberikan guru melalui aplikasi Quizizz dan dapat membantu pekerjaan rumah. Sebagimana hasil telaah dokumen yang ditemukan yaitu guru hanya memberikan soal pilihan ganda kepada siswa, melalui portal guru diaplikasi Quizizz. Hal ini juga sesuai dengan teori yang dikemukakan oleh Citra \& Rosy (2020) bahwa media aplikasi Quizizz hanya dapat digunakan untuk mengetahaui kemampuan siswa dalam memahami materi dengan memberikan soal- soal.

Fitur yang ada di dalam Quizizz media pembelajaran Quizizz sangat banyak seperti fitur soal pilihan ganda, isian singkat, survei, esai dan meluncur. Berdasarkan hasil penelitian guru hanya memanfaatkan fitur soal pilihan ganda pada aplikasi Quizizz dalam pembelajaran daring. Siswa hanya mengerjakan soal pilihan ganda ketika menggunakan aplikasi Quizizz dalam pembelajaran daring. Menurut orang tua/ wali murid guru hanya memberikan fitur soal pilihan ganda pada aplikasi Quizizz. Sebagaimana telaah dokumen yang ditemukan yaitu gambar fitur pertanyaan yang ada diaplikasi Quizizz yaitu pilihan ganda, isian singkat, survei, esai dan meluncur. Kemudiaan juga ditemukan dokumen yakni, gambar bentuk soal pilihan ganda yang digunakan guru diaplikasi Quizizz. Hal ini juga sesuai dengan teori yang dikemukakan oleh Basuki (n,d) bahwa guru dapat memilih soal pilihan ganda, banyak jawaban, isian singkat, survei, esai dan meluncur.

Penelitian yang peneliti lakukan diperkuat oleh penelitian yang dilakukan oleh Salsabila (2020) dengan judul "Pemanfaatan Aplikasi Quizizz Sebagai Media Pembelajaran Ditengah Pandemi Pada Siswa SMA". Pada masa pandemi covid- 19 pemerintah secara tidak langsung mengambil kebijakan dimana proses belajar dan pembelajaran dilakukan secara daring. Proses belajar dan pembelajaran daring adalah dimana proses pembelajaran yang dilakukan guru dan siswa tidak dilakukan tatap muka melainkan di tempat masingmasing. Sehingga guru dan siswa membutuhkan media pembelajaran yang berbeda sebagai sarana untuk menyampaikan informasi salah satunya adalah aplikasi Quizizz.

\section{KESIMPULAN}

Berdasarkan pembahasan mengenai menganalisis media pembelajaran Quizizz dalam pembelajaran daring kelas IV SD Muhammadiyah 6 Samarinda Utara bahwa menggunakan aplikasi Quizizz yang mempunyai banyak fitur menarik dapat menumbuhkan motivasi dan minat belajar siswa. Menggunakan 
4800 Analisis Media Pembelajaran Quizizz dalam Pembelajaran Daring pada Siswa Tingkat Sekolah Dasar - Gamar Al Haddar, Maulana Adam Juliano

DOI: https://doi.org/10.31004/edukatif.v3i6.1512

aplikasi Quizizz juga menjadikan proses pembelajaran daring menjadi menyenangkan. Kendala dalam penggunaan aplikasi Quizizz adalah jaringan internet yang tidak menentu dapat menyebabkan siswa tidak bisa login dan bisa keluar dari aplikasi Quizizz. Penggunaan kouta internet untuk mengakses aplikasi Quizizz menjadi kendala karena susah menghubungkan ke-jaringan internet. Manfaat ketika menggunakan aplikasi Quizizz guru dapat mengatur kapan batas waktu mengerjakan tugas sehingga siswa selalu tepat waktu mengerjakan tugas. Penggunaan aplikasi Quizizz yang mempunyai banyak fitur menarik dan ada durasi waktu mengerjakan soal yang dapat disetting guru membuat proses pembelajaran daring lebih variatif dan efisien. Kelebihan menggunakan aplikasi Quizizz hasil belajar dapat dilihat secara langsung oleh siswa berupa skor dan ragkingnya, sedangkan untuk guru ada rekap nilainya. Penggunaan aplikasi Quizizz juga dapat mengevaluasi siswa secara mandiri dikarenakan guru memberikan jawaban benar ketika siswa menjawab salah dan siswa juga dapat kesempatan untuk memperbaiki nilainya dengan mengerjakan soal yang sama apabila nilai siswa rendah. Fitur- fitur soal yang ada di dalam aplikasi Quizizz hanya untuk mengetahui kemampuan siswa dalam ranah kognitif. Salah satu fitur yang digunakan guru adalah pilihan ganda.

\section{UCAPAN TERIMA KASIH}

Peneliti mengucapkan terima kasih kepada Universitas Widya Gama Mahakam Samarinda Kalimantan Timur atas dukungannya dalam penelitian ini baik secara moril maupun materiil. Peneliti juga mengucapkan terimakasih kepada SD Muhammadiyah 6 Samarinda Utara atas kerjasamanya dan izin yang telah diberikan kepada peneliti untuk melaksanakan penelitian di sekolah tersebut.

\section{DAFTAR PUSTAKA}

Amanah, S. A. N., Iwan, C. D., \& Selamet. (2020). Pengaruh Penggunaan Aplikasi Quizizz Terhadap Efektivitas Pembelajaran PAI. Jurnal Bestari, 17(1), 117-132.

Abidin, Z., Hudaya, A., \& Anjani, D. (2020). Efektivitas Pembelajaran Jarak Jauh Pada Masa Pandemi Covid19. Research and Development Journal of Education, 1(1), 131.

Arsyad, A. (2017). Media Pembelajaran (2O ed.). PT. RajaGrafindo.

Basuki, Y. R. (n.d.). Panduan Mudah Quizizz.

Citra, C. A., \& Rosy, B. (2020). Keefektifan Penggunaan Media Pembelajaran Berbasis Game Edukasi Quizizz Terhadap Hasil Belajar Teknologi Perkantoran Siswa Kelas X SMK Ketintang Surabaya. Jurnal Pendidikan Administrasi Perkantoran (JPAP), 8, 261-272.

Daryanto, T. R. dan. (2015). Teori Belajar dan Proses Pembelajaran yang Mendidik (1st ed.). Gava Media

Dewi, C., \& Asrori, M. (2019). Analisis Pembelajaran Dalam Mengembangkan Dikemandirian Pada Anak Usia 5-6 Tahun di tk Pertiwi 1 Pontianak.

Dimyanti, M. (2015). Belajar Dan Pembelajaran (5th ed.). PT Rineka Cipta.

Elyas, A. H. (2018). Penggunaan Model Pembelajaran E-Learning Dalam Meningkatkan Kualitas Pembelajaran. Jurnal Warta, 56(04), 1-11.

Furkan, F., Sya, A., Purwanto, A., \& Astra, I. M. (2021). Tantangan Guru dalam Penggunaan Metode Pembelajaran Jarak Jauh (PJJ). EDUKATIF: JURNAL ILMU PENDIDIKAN, 3(6), 3877-3883.

Pane, A., \& Darwis Dasopang, M. (2017). Belajar Dan Pembelajaran. FITRAH:Jurnal Kajian Ilmu-Ilmu Keislaman, 3(2), 333.

Pohan, A. E. (2020). Konsep Pembelajaran Daring Berbasis Pendekatan Ilmiah. CV. Sarnu Untung.

Prasetyo, T., Zulela, M. S., \& Fahrurrozi, F. (2021). Analisis Berpikir Kreatif Mahasiswa dalam Pembelajaran Daring Bahasa Indonesia. EDUKATIF: JURNAL ILMU PENDIDIKAN, 3(6), 3617-3628. 
4801 Analisis Media Pembelajaran Quizizz dalam Pembelajaran Daring pada Siswa Tingkat Sekolah Dasar - Gamar Al Haddar, Maulana Adam Juliano

DOI: https://doi.org/10.31004/edukatif.v3i6.1512

Sanjaya, W. (2016). Strategi Pembelajaran Berorientasi Standar Proses Pendidikan (12th ed.). Prenadamedia Group.

Suciningsih. (2020). Dalam Masa Covid-19 di MI Muhammadiyah.

Sugiyono. (2015). Metode Penelitian kuantitatif, kualitatif, dan R dan D (22nd ed.). Alfabeta, CV.

Suhartatik, T. (2020). Imlementasi Media Quizizz berbasis Android Terhadap Kualitas Pembelajarandalam Mencetak Siswa Berprestasi di Tingkat Nasional (1st ed.). CV. Multimedia Edukasi.

Susanto, A. (2016). Teori Belajar dan Pembelajaran di Sekolah Dasar (4th ed.). kencana.

Salsabila, U. H., Habiba, I. S., Amanah, I. L., Istiqomah, N. A., \& Difany, S. (2020). Pemanfaatan Aplikasi Quizizz Sebagai Media Pembelajaran Ditengah Pandemi Pada Siswa SMA. Jurnal Ilmiah Ilmu Terapan Universitas Jambi| JIITUJ|, 4(2), 163-173. 